\title{
USE OF METAMITRON AS AN APPLE THINNER ${ }^{1}$
}

\author{
GENTIL CARNEIRO GABARDO ${ }^{2}$, JOSÉ LUIZ PETRI ${ }^{3}$, FERNANDO JOSÉ HAWERROTH ${ }^{4}$, \\ MARCELO COUTO ${ }^{3}$, LUIZ CARLOS ARGENTA ${ }^{3}$, AIKE ANNELIESE KRETZSCHMAR ${ }^{2}$
}

\begin{abstract}
The aim of this study was to evaluate the efficacy of metamitron or metamitron plus benzyladenine as a post-bloom thinner on 'Baronesa' and 'Fuji' apples. Three experiments (rate, timing and BA combination) were conducted during two crop seasons, 2013/14 and 2014/15 at the experimental station located in Caçador, SC. Fruit set, fruit drop, yield per tree, fruit size and flowering return were assessed. The efficacy of metamitron was affected by time of application, and when applied at petal fall, promoted the proper adjustment of the production load of plants. Yield per plant reduces, whereas the allocation of fruits in categories of greater size increases proportionally to the increase in the metamitron concentration applied. However, there is excessive fruit drop with the use of high concentrations. The addition of BA to metamitron also promoted fruit drop; however, no difference was observed between single application of metamitron and BA addition. Metamitron shows great potential to be used as thinner for apples, since it reduces the number of fruits per tree.
\end{abstract}

Index terms: Malus domestica, post-bloom thinning, fruit drop, return bloom, fruit quality.

\section{METAMITRON NO RALEIO QUÍMICO DA MACIEIRA}

RESUMO - O objetivo deste estudo foi avaliar o efeito de diferentes épocas e concentrações de metamitron e a mistura com benziladenina, no raleio químico em pós-floração das macieiras 'Baronesa' e 'Fuji'. Foram conduzidos três experimentos durante as safras agrícolas de 2013/2014 e 2014/2015, no município de Caçador-SC. Foram avaliados: a frutificação efetiva, a queda de frutos, a produção por planta, a distribuição dos frutos em classes de calibre e o retorno de floração. A época de aplicação de metamitron influenciou a eficiência do produto, sendo que, quando aplicado na queda de pétalas, este promoveu o adequado ajuste da carga produtiva das plantas. A produção por planta reduz, enquanto a alocação dos frutos em categorias de maior calibre aumenta, proporcionalmente ao aumento da concentração de metamitron aplicada. No entanto, há queda excessiva de frutos com a utilização de concentrações elevadas. A mistura de metamitron com benziladenina, promove a queda de frutos, porém não há efeito aditivo entre a mistura e a aplicação individual de metamitron. O princípio ativo metamitron tem potencial para uso num programa de raleio químico em macieira, visto que reduz a frutificação.

Termos para indexação: Malus domestica, raleio em pós-floração, queda de frutos, retorno de floração, qualidade de frutos.

\footnotetext{
'(Paper 002-16). Received January 08, 2016. Accepted April 08, 2016.

${ }^{2}$ University of the State of Santa Catarina, Department of Agrarian Sciences. Lages-SC.Emails: ge.gabardo@gmail.com; aikeanneliese@ yahoo.com.br

${ }^{3}$ Epagri / Experimental Station of Caçador, Caçador - SC. Emails: petri@epagri.sc.gov.br; marcelocouto@epagri.sc.gov.br; argenta@ epagri.sc.gov.br

${ }^{4}$ Embrapa Grape and Wine, Experimental Station of Temperate fruit crops, Vacaria-RS. Email: fernando.hawerroth@embrapa.br
} 


\section{INTRODUCTION}

In apple crop, thinning aims to reduce fruit set, particularly in years where climatic conditions favor excessive floral induction, adjusting the number of fruits per plant to increase the proportion of fruits in higher size categories and commercial acceptance, also avoiding production alternation (STOVER et al., 2004; REIGHARD et al, 2006). Chemical thinning is promising because it is a quick operation and allows thinning flowers and fruits at the right moment, guaranteeing better quality of fruits and significantly reducing labor costs when compared to hand thinning (COSTA et al., 2006).

Due to the great climatic variability observed in the southern region of Brazil, fruit set from year to year is very variable, so that the evaluation of the need and intensity of thinning can only be performed after fertilization, making chemical thinning at flowering a practice of great risk for producers (PETRI et al., 2013). Post-bloom chemical thinning is the most indicated when abundant flowering and high fruit set are observed (PETRI et al., 2006). However, COSTA et al (2004) highlight the low availability of thinning products, especially in areas under strict regulatory controls for the registration of new molecules, requiring the development of new environmentally safe and highly efficient products, such as benzyladenine.

Herbicide metamitron is an inhibitor of photosystem II, belonging to triazinone chemical group, which has recently been reported as efficient product in the thinning of apple crops (LAFER, 2010; BASAK, 2011; STERN, 2014), as it affects the photosynthetic apparatus for 7 to 10 days after application, reducing electron transport rates by up to $60 \%$ (MCARTNEY; OBERMILLER, 2012). The 'metamitron' active principle is effective in the chemical thinning of apple trees when applied at the stage of petal fall until fruit reaches a diameter of up to $18 \mathrm{~mm}$ (BASAK, 2011), which effect may be enhanced when associated with other thinners (MCARTNEY; OBERMILLER, 2012; GREENE, 2014). The decrease in plant fructification as well as the increase in mean fresh fruit weight is proportional to the increase in the metamitron concentration applied (BRUNNER, 2014; GREENE, 2014; STERN, 2014). However, MCartney and Obermiller (2014) point out the possibility of excessive fruit drop depending on the concentration and application stage of this plant growth regulator. In addition, the effect of chemical thinners is dependent on the interaction between genotype and climatic conditions, and should therefore be tested in each producing region (PETRI et al., 2013). In view of the limited availability of thinners for apple trees, studies with metamitron are needed for the improvement of the chemical thinning and subsequent use by the productive sector in Brazil.

The aim of this study was to evaluate the effect of different times of application and metamitron concentrations applied either alone or in combination with benzyladenine on post-bloom chemical thinning of 'Baronesa' and 'Fuji' apple cultivars.

\section{MATERIAL AND METHODS}

The work consisted of three experiments in 2013/2014 and 2014/2015 crop seasons conducted at an experimental orchard located in the municipality of Caçador, SC (26 $46^{\circ}$ 'S, $51^{\circ} 00^{\prime} \mathrm{W}$ and $960 \mathrm{~m}$ a.s.1.).

In experiment 1, 12-year-old apple trees Baronesa / M-26 cultivar were used at planting density of 2,500 plants ha ${ }^{-1}$. Baronesa apple cultivar is of high fruit set and little responsive to chemical thinners, similarly to 'Fuji' cultivar (CAMILO; DENARDI, 2006). Four times of metamitron application at $350 \mathrm{mg} \mathrm{L}^{-1}$ (petal fall - QP, fruits from 5 to $10 \mathrm{~mm}$ in diameter, fruits from 15 to $20 \mathrm{~mm}$ in diameter, and fruits greater than $20 \mathrm{~mm}$ in diameter) were evaluated and hand thinning treatment and control treatment (plants without thinning) were compared.

In experiment 2, 12-year-old Baronesa/ M-26 apple trees were used at planting density of 2,500 plants ha ${ }^{-1}$, and six metamitron concentrations (0 mg L ${ }^{-1}, 350 \mathrm{mg} \mathrm{L}^{-1}, 700 \mathrm{mg} \mathrm{L}^{-1}, 1050 \mathrm{mg} \mathrm{L}^{-1}$, $1400 \mathrm{mg} \mathrm{L}^{-1}$ and $\left.1750 \mathrm{mg} \mathrm{L}^{-1}\right)$ in a single application performed when fruits were 20 to $25 \mathrm{~mm}$ in diameter $(11 / 11 / 2013)$.

In experiment 3 , two metamitron concentrations ( $350 \mathrm{mg} \mathrm{L}^{-1}$ and $700 \mathrm{mg} \mathrm{L}^{-1}$ ), applied alone or in combination with benzyladenine (BA) at $0.8 \mathrm{mg} \mathrm{L}^{-1}$ were tested in a single application period (fruits from 5 to $10 \mathrm{~mm}$ in diameter), comparing with hand thinning and plants without thinning (control). Twenty-four-year-old Fuji / M-7 apple trees at planting density of $1000 \mathrm{ha}^{-1}$ plants in the 2013/2014 and 2014/2015 crop seasons were used. In the $2013 / 2014$ crop season, treatments were applied on $10 / 22 / 2013$, when most fruits were 5 to $10 \mathrm{~mm}$ in diameter and hand thinning was performed on $11 / 01 / 2013$. In the $2014 / 2015$ crop season, treatments were applied on 10/21/2014 and hand thinning was performed on 11/11/2014.

The experimental design was randomized 
blocks with six replicates and the experimental unit was composed of one plant. Commercial product Goltix ${ }^{\circledR} 700$ SC WG (70\% i.a.) was used as source of metamitron, and commercial product MaxCel ${ }^{\circledR}$ ( $2 \%$ i.a.) was used as source of benzyladenia (BA). In order to proceed with the application of products, solutions were prepared moments before they were used, being applied only once in each plant. Products were applied with a motorized costal sprayer $(20 \mathrm{~L})$ containing three fan-type D-S nozzles, with syrup volume equivalent to $1000 \mathrm{~L} \mathrm{ha}^{-1}$. The diameter $(\mathrm{mm})$ of the equatorial section of fruits was measured with a pachymeter, randomly in the plants, and when fruits were in the desired phase, thinners were applied. Hand thinning adopted the criterion of maintaining one (01) and two (02) fruits in the fruiting structures of twig and spur type, respectively, and in the chemical thinning, no hand thinning supplement was performed.

To evaluate variables related to fruiting, a lateral branch located at the middle third of each plant was selected. Fruit set (\%), number of fruits per inflorescence, fruit drop (\%) and flowering return (\%) were estimated. Fruit set, expressed as a percentage, was obtained by the relationship between total number of fruits counted before and 30 days after the application of treatments and the number of inflorescences counted during full bloom ([initial number of fruits / number of inflorescences] $X$ 100). The number of fruits per inflorescence was estimated by counting the number of fruits in each inflorescence before and 30 days after the application of treatments. Fruit drop, expressed as a percentage, was given by the relationship between final number of fruits and initial number of fruits ([final number of fruits / initial number of fruits] x 100); flowering return was estimated in the production cycle after the application of thinning treatments, and was obtained from counting the total number of buds and number of flowering buds on the marked branch ([number of flowering buds / total number of buds] x 100), expressed as a percentage.

Harvest was individually performed for each plant in a single pass-through and afterwards the fresh weight of fruits of each plant was measured with a digital scale with accuracy of $\pm 0.01 \mathrm{~kg}$, and data were expressed in $\mathrm{kg}_{\text {plant }}{ }^{-1}$. Then, fruits were counted (fruits plant ${ }^{-1}$ ) and the relationship between total fresh weight and the total number of fruits harvested was used to obtain the average fresh weight of fruits $(\mathrm{g})$. Fruits were classified into three categories, according to the size: $<135$ ( $>141 \mathrm{~g})$; 136165 (105 to $141 \mathrm{~g})$; and $\geq 180(\leq 104 \mathrm{~g})$ and then the percentage of fruits per size category was calculated.
In a sample of twenty fruits per treatment, physicochemical characteristics pulp firmness (Lib in $^{-2}$ ), iodine-starch index, total soluble solids content $\left({ }^{\circ}\right.$ Brix) and titratable acidity (\% malic acid) were evaluated according to methodology described by Scolaro et al. (2015).

Data expressed as a percentage were transformed using the equation sine $\operatorname{arc}(\mathrm{x} / 100)^{1 / 2}$. Data obtained were submitted to analysis of variance (ANOVA), and the significant variables by the $\mathrm{F}$ test $(\mathrm{P} \leq 0.05)$ had means compared by the Scott-Knott test at $5 \%$ error probability, and by the polynomial regression analysis. Statistical analyses used the Sisvar software, version 5.3 (FERREIRA, 2010).

\section{RESULTS AND DISCUSSION}

In 'Baronesa' apple trees, no change in the mean number of fruits per inflorescence among times of metamitron application at $350 \mathrm{mg} \mathrm{L}^{-1}$ was observed (Table 1). Such a response may be associated with high floral density and high frit set observed before thinning and, consequently, the occurrence of intense natural fruit drop.

Significant difference with reduction in the number of fruits per plant was verified with the use of metamitron at $350 \mathrm{mg} \mathrm{L}^{-1}$ in the stage of petal fall and in fruits with 5 to $10 \mathrm{~mm}$ in diameter, as well as in plants submitted to hand thinning, compared to the other treatments. There was no difference among treatments for fruit weight per plant. The mean fresh fruit weight increased with the application of 350 $\mathrm{mg} \mathrm{L}^{-1}$ metamitron in the petal fall phase compared to the other treatments, since benefits are higher at this stage due to intense cell division. Similar results were reported by Lafer (2010), in which applications of $350 \mathrm{mg} \mathrm{L}^{-1}$ metamitron in early fruit development stages ( 6 to $8 \mathrm{~mm}$ in diameter) significantly reduced the number of fruits per plant in 'Elstar' apple trees, while later applications (12 to $14 \mathrm{~mm}$ ) did not differ from untreated plants. The abscission of smaller fruits can be enhanced when associated to climatic conditions that favor the reduction of carbohydrate levels in plants, especially low light levels and high temperature after application (FALLAHI and GREENE, 2010).

The flowering return in the year after the application of chemical thinners should also be considered in the selection of new substances for use. In the study of times of metamitron application, the highest flowering return was observed in plants manually thinned (34.9\%), followed by metamitron applications at $350 \mathrm{mg} \mathrm{L}^{-1}$, during the period of petal fall and in fruits with diameter greater than 
$20 \mathrm{~mm}$. For plants in which $350 \mathrm{mg} \mathrm{L}^{-1}$ metamitron was applied at with fruits from 5 to $10 \mathrm{~mm}$ or 11 to $15 \mathrm{~mm}$ in diameter, no difference was observed in comparison to control plants regarding the flowering return. Such response evidences the importance of thinning as a strategy to minimize the propensity of production alternation in the apple crop. Basak (2011) observed that $350 \mathrm{mg} \mathrm{L}^{-1}$ metamitron applied only once in fruits from 6 to $8 \mathrm{~mm}$ in diameter, or in two times, one in fruits from 6 to $8 \mathrm{~mm}$ and another in fruits from 10 to $16 \mathrm{~mm}$ in diameter, did not interfere with the flowering of the subsequent year in 'Gala Must' apple trees. Similarly, Stern (2014) reported that plants treated with metamitron did not undergo any change in flowering return, although the concentration used was lower. On the other hand, Lafer (2010) reported that the flowering return was extremely related to the harvest load of the previous year, since plants with smaller yields had higher flowering return.

There was a significant difference in fruit distribution per size class when $350 \mathrm{mg} \mathrm{L}^{-1}$ metamitron was applied in the period of petal fall and hand thinning of fruits in relation to the other treatments, and in both treatments, there was an increase in the percentage of fruits in the highest size class (135) and reduction of the proportion of fruits in the lowest size class (180) (Table 2). These data are similar to those obtained by Stern (2014), who evaluated metamitron at $130 \mathrm{mg} \mathrm{L}^{-1}$ in two applications, one in the period of full bloom followed by another, seven days after, or one in full bloom and another 14 days after and also observed reduction in the number of fruits in the category considered small fruits and increase in the number of fruits in the medium and large fruit size categories.

The physicochemical fruit characteristics pulp firmness and starch index did not differ among times of metamitron application, but the soluble solids content was higher when thinner was applied at $350 \mathrm{mg} \mathrm{L}^{-1}$ in the period of petal fall. Greene (2014) observed that applications of metamitron in combination with benzyladenine determined slight changes in variables related to fruit maturation, pulp firmness and soluble solids.

Evaluating the use of metamitron at different concentrations in 'Baronesa' apple trees, a direct proportional relationship was observed between concentration of this phytorregulator and fruit drop (Figure 1a). This increase in fruit drop associated with increased metamitron concentration has also been reported for 'Golden Delicious' (BRUNNER, 2014) and 'CandyCrisp' apple trees (GREENE, 2014). It is noteworthy that there was a $31.6 \%$ reduction in the number of fruits per inflorescence in plants treated with $1750 \mathrm{mg} \mathrm{L}^{-1}$ metamitron compared to untreated plants. According to McArtney and Obermiller (2014), high concentrations of this thinner can promote excessive fruit drop, requiring some care during application.

With the increase in the thinner concentration applied, there was a significant reduction in the number of fruits per inflorescence (Figure 1b) and in the total number of fruits per plant (Figure 1c). Brunner (2014) evaluated the use of metamitron at concentrations ranging from 0 to $990 \mathrm{mg} \mathrm{L}^{-1}$ applied in the thinning of "Golden Delicious" fruits with 8 $\mathrm{mm}$ in diameter and observed that the decrease in the production per plant was proportional to the increase in concentration, and the application of $990 \mathrm{mg} \mathrm{L}^{-1}$ determined the reduction of $8.5 \%$ in production per plant and $35.8 \%$ in the number of fruits compared to untreated plants.

The maximum increase in mean fresh fruit weight was obtained at concentration of $1050 \mathrm{mg}$ $\mathrm{L}^{-1}$ when compared to control plants (Figure $1 \mathrm{~g}$ ). On the other hand, the highest fruit weight per plant was obtained in the control treatment (Figure 1h). The increase in the mean fresh fruit weight provided by the use of metamitron at higher concentrations resulted in an increase in the proportion of fruits in the highest size classes (Figures 1d, 1e and 1f). The higher allocation of fruits in greater size categories observed in this work corroborates results obtained by Stern (2014) in 'Gala' apple trees and Brunner (2014) in 'Golden Delicious' apple trees, in which larger fruits generally have better commercial acceptance, evidencing the importance of thinning as a strategy to improve the quality of fruits produced.

It is noteworthy that the use of different metamitron concentrations for the thinning of 'Baronesa' apple trees did not change the flowering return in the cycle after application when compared to untreated plants (Figure 1i). Likewise, this result was observed when using metamitron in combination with benziladenine in 'Fuji' apple trees (Table 3). Similar results have been reported by Stern (2014), who observed no change in flowering return on metamitron-treated 'Gala' apple trees, but Brunner (2014) reported great variability in flowering density in response to metamitron use according to cultivar and times of application. The experiment related to the study of times of metamitron application in 'Baronesa' apple trees also evidenced differences among treatments.

In the 2013/2014 crop season, the use of the combination of $350 \mathrm{mg} \mathrm{L}^{-1}$ metamitron and $0.8 \mathrm{mg} \mathrm{L}^{-1}$ benzyladenine and the use of $700 \mathrm{mg} \mathrm{L}^{-1}$ metamitron 
significantly reduced fruit set after application in relation to the other treatments. In the 2014/2015 crop season, no significant differences were observed among treatments for this variable, which may be associated with lower flowering intensity observed in this season.

In the 2013/2014 crop season, all treatments with metamitron, regardless of concentration adopted, alone or combined with benzyladenine, promoted fruit drop rates higher than $50.9 \%$, exceeding hand thinning treatment. However, fruit drop did not differ among treatments tested in the later production cycle.

The mean number of fruits per inflorescence was not influenced by the use of metamitron, alone or in mixture with benzyladenine, in both crop seasons evaluated. For the average number of fruits per plant, there was a decrease in the 2013/2014 crop season compared to control plants, plants treated with $350 \mathrm{mg} \mathrm{L}^{-1}$ metamitron, $350 \mathrm{mg} \mathrm{L}^{-1}$ metamitron in combination with $0.8 \mathrm{mg} \mathrm{L}^{-1}$ benzyladenine and $700 \mathrm{mg} \mathrm{L}^{-1}$ metamitron, respectively, but without alteration in the total fresh weight of fruits produced per plant. In the subsequent production cycle, there was a reduction in the number and total fresh weight of fruits produced in plants treated with 350 $\mathrm{mg} \mathrm{L}^{-1}$ metamitron in combination with $0.8 \mathrm{mg} \mathrm{L}^{-1}$ benzyladenine and $700 \mathrm{mg} \mathrm{L}^{-1}$ metamitron, alone and in combination with $0.8 \mathrm{mg} \mathrm{L}^{-1}$ benzyladenine.

A significant difference was observed in the distribution of fruits in greater size classes for treatments $350 \mathrm{mg} \mathrm{L}^{-1}$ metamitron $+0.8 \mathrm{mg} \mathrm{L}^{-1}$ benziladenine, $700 \mathrm{mg} \mathrm{L}^{-1}$ metamitron and 700 $\mathrm{mg} \mathrm{L}^{-1}$ metamitron $+0.8 \mathrm{Mg} \mathrm{L}^{-1}$ benziladenine in the $2013 / 2014$ crop season in relation to the other treatments (Table 4). This higher allocation of fruits in higher size categories was also reported by Stern (2014), who worked with applications of different metamitron dosages in 'Gala' apple trees.

TABLE 1-Average number of fruits per inflorescence after thinning, average number and fresh weight of fruits per plant, average fresh weight of fruits and flowering return of 'Baronesa' apple trees submitted to different treatments for fruit thinning in the 2013 / 2014 crop season. Caçador, SC, 2015.

\begin{tabular}{|c|c|c|c|c|c|}
\hline Treatments & $\begin{array}{l}\text { Average number } \\
\text { of fruits per } \\
\text { inflorescence }\end{array}$ & $\begin{array}{c}\text { Average } \\
\text { number } \\
\text { of fruits } \\
\text { per plant }\end{array}$ & $\begin{array}{l}\text { Weight of } \\
\text { fruits per } \\
\text { plant }\end{array}$ & $\begin{array}{l}\text { Average } \\
\text { fresh weight } \\
\text { of fruits }\end{array}$ & $\begin{array}{l}\text { Flowering } \\
\text { return }\end{array}$ \\
\hline & - & - & $\mathrm{kg}$ & $\mathrm{g}$ & $\%$ \\
\hline Control (no thinning) & $1.9^{\text {ns }}$ & $602.2 \mathrm{a}$ & $47.5^{\mathrm{ns}}$ & $81.0 \mathrm{~b}$ & $13.3 \mathrm{c}$ \\
\hline Hand thinning & 1.5 & $340.2 \mathrm{~b}$ & 35.6 & $112.5 \mathrm{~b}$ & $34.9 \mathrm{a}$ \\
\hline $350 \mathrm{mg} \mathrm{L}^{-1} \mathrm{MM}$ (petal fall) & 1.7 & $246.8 \mathrm{~b}$ & 32.6 & $143.6 \mathrm{a}$ & $23.0 \mathrm{~b}$ \\
\hline $350 \mathrm{mg} \mathrm{L}^{-1} \mathrm{MM}$ (Ø from 5 to $10 \mathrm{~mm}$ ) & 1.9 & $369.8 \mathrm{~b}$ & 35.7 & $99.1 \mathrm{~b}$ & $8.9 \mathrm{c}$ \\
\hline $350 \mathrm{mg} \mathrm{L}^{-1} \mathrm{MM}$ (Ø from 10 to $15 \mathrm{~mm}$ ) & 2.0 & $460.5 \mathrm{a}$ & 42.0 & $94.3 \mathrm{~b}$ & $9.0 \mathrm{c}$ \\
\hline $350 \mathrm{mg} \mathrm{L}^{-1} \mathrm{MM}(\varnothing>20 \mathrm{~mm})$ & 1.8 & $476.8 \mathrm{a}$ & 39.5 & $92.1 \mathrm{~b}$ & $16.1 \mathrm{~b}$ \\
\hline $\mathrm{CV}(\%)$ & 17.0 & 19.9 & 29.5 & 18.0 & 13.3 \\
\hline
\end{tabular}

${ }^{n s}$ not significant $(\mathrm{P}>0.05)$. Averages followed by the same letter in the column do not differ from each other by the Scott-Knott test at $5 \%$ error probability. MM: metamitron; CV: Coefficient of variation; Ø: diameter of fruits. 
TABLE 2- Distribution of fruits by size, pulp firmness, total soluble solids content and iodine-starch index of 'Baronesa' apple fruits submitted to different fruit thinning treatments in the 2013/2014 crop season.

\begin{tabular}{|c|c|c|c|c|c|c|}
\hline \multirow{2}{*}{ Treatments } & \multicolumn{3}{|c|}{ Fruit distribution by size } & \multirow{2}{*}{$\begin{array}{c}\text { Pulp } \\
\text { firmness }\end{array}$} & \multirow{2}{*}{ TSS } & \multirow{2}{*}{ Iodine Starch } \\
\hline & $>135^{1}$ & $136-165^{2}$ & $\geq 180^{3}$ & & & \\
\hline & & $(\%)$ & & lib $\mathrm{cm}^{-2}$ & $(\%)$ & Scale (0-9) \\
\hline Control (no thinning) & $4.2 \mathrm{~b}$ & $29.6^{\mathrm{ns}}$ & $66.2 \mathrm{a}$ & $16.0^{\mathrm{ns}}$ & $11.6 \mathrm{~b}$ & $4.4^{\mathrm{ns}}$ \\
\hline Hand thinning & $25.7 \mathrm{a}$ & 45.5 & $28.8 \mathrm{~b}$ & 16.1 & $11.7 \mathrm{~b}$ & 2.7 \\
\hline $350 \mathrm{mg} \mathrm{L}^{-1} \mathrm{MM}$ (petal fall) & $37.8 \mathrm{a}$ & 49.2 & $13.0 \mathrm{~b}$ & 15.9 & $13.3 \mathrm{a}$ & 3.5 \\
\hline $350 \mathrm{mg} \mathrm{L}^{-1} \mathrm{MM}$ (Ø from 5 to $10 \mathrm{~mm}$ ) & $12.0 \mathrm{~b}$ & 45.5 & $42.5 \mathrm{a}$ & 16.0 & $12.5 \mathrm{~b}$ & 3.5 \\
\hline $350 \mathrm{mg} \mathrm{L}^{-1} \mathrm{MM}$ (Ø from 10 to $15 \mathrm{~mm}$ ) & $7.7 \mathrm{~b}$ & 39.2 & $53.2 \mathrm{a}$ & 16.3 & $11.9 \mathrm{~b}$ & 3.3 \\
\hline $350 \mathrm{mg} \mathrm{L}^{-1} \mathrm{MM}(\varnothing>20 \mathrm{~mm})$ & $10.0 \mathrm{~b}$ & 40.2 & $49.8 \mathrm{a}$ & 16.4 & $12.1 \mathrm{~b}$ & 2.5 \\
\hline $\mathrm{CV}(\%)$ & 53.3 & 15.8 & 30.1 & 3.9 & 4.7 & 36.9 \\
\hline
\end{tabular}

${ }^{n s}$ not significant $(\mathrm{P}>0.05)$. Means followed by the same letter in the column do not differ from each another by the Scott-knott test at $5 \%$ error probability. MM: metamitron; Ø: fruit diameter; Size> 135 (fruit weighing more than $141 \mathrm{~g}$ ); size from 136 to 165 (fruit with weight ranging from 105 to $141 \mathrm{~g}$ ); size $\geq 180$ (fruit with weight equal to or less than $104 \mathrm{~g}$ ); CV - Coefficient of variation.

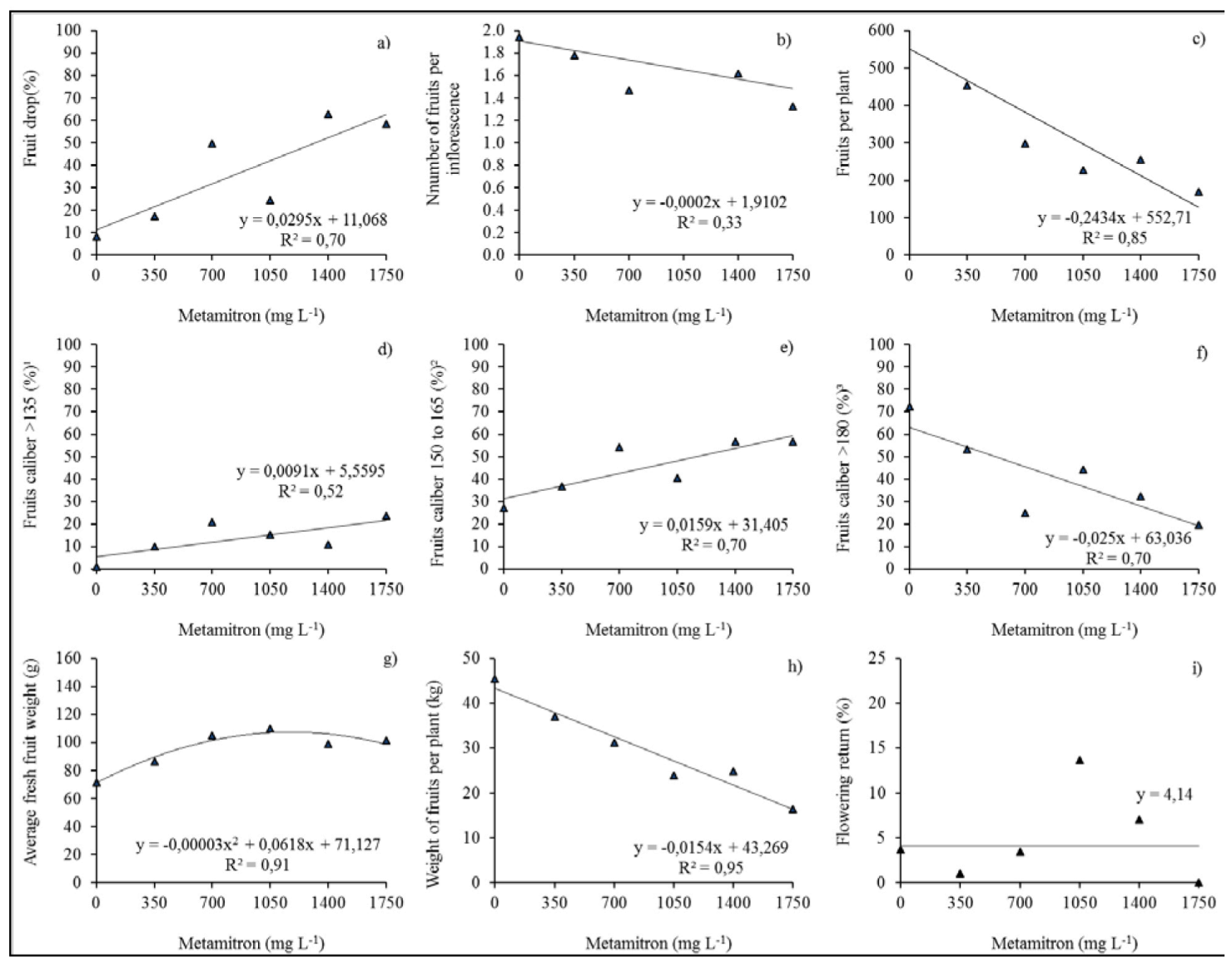

FIGURE 1 - Fruit drop (a), average number of fruits per inflorescence (b), fruits per plant (c); distribution of fruit by size class (d, e, f): (1)> 135 (fruit weighing more than $141 \mathrm{~g}$ ); (2) 150 to 165 (fruits with weight ranging from 105 to $141 \mathrm{~g}$ ); (3) $\geq 180$ (fruit weighing $104 \mathrm{~g}$ or less); average fresh fruit weight $(\mathrm{g})$; weight of fruits per plant $(\mathrm{h})$ and flowering return of 'Baronesa' apple plants treated with different MM concentrations $\left(\mathrm{mg} \mathrm{L}^{-1}\right)$ (i), in the 2013/2014 crop season. Caçador-SC, 2015. 
TABLE 3 - Fruit set, fruit drop, number of fruits per inflorescence, fruit weight per plant, average number of fruits per plant and average fresh weight of fruits under effect of post-bloom thinning of 'Fuji' apple trees in 2013/2014 and 2014/2015 crop seasons.

\begin{tabular}{|c|c|c|c|c|c|c|c|}
\hline \multirow[t]{3}{*}{ Treatments } & Fruit set & Fruit drop & $\begin{array}{c}\text { Average number } \\
\text { of fruits per } \\
\text { inflorescence }\end{array}$ & $\begin{array}{l}\text { Fresh } \\
\text { weight of } \\
\text { fruits per } \\
\text { plant }\end{array}$ & $\begin{array}{c}\text { Average } \\
\text { number of } \\
\text { fruits per } \\
\text { plant }\end{array}$ & $\begin{array}{c}\text { Average } \\
\text { fresh weight } \\
\text { of fruits }\end{array}$ & $\begin{array}{l}\text { Flowering } \\
\text { return }\end{array}$ \\
\hline & $\%$ & $\%$ & - & $\mathrm{kg}$ & - & $\mathrm{g}$ & $\%$ \\
\hline & \multicolumn{7}{|c|}{---------2013/2014--------- } \\
\hline $\begin{array}{l}\text { Control } \\
\text { (No thinning) }\end{array}$ & $82.1 \mathrm{a}$ & $24.6 \mathrm{~b}$ & $1.69^{\mathrm{ns}}$ & $65.4^{\mathrm{ns}}$ & $654.8 \mathrm{a}$ & $107.4 \mathrm{c}$ & $36.8^{\mathrm{ns}}$ \\
\hline Hand thinning & $101.4 \mathrm{a}$ & $24.5 \mathrm{~b}$ & 1.73 & 75.7 & $666.0 \mathrm{a}$ & $114.5 \mathrm{c}$ & 57.6 \\
\hline $350 \mathrm{mg} \mathrm{L}^{-1} \mathrm{MM}$ & $67.7 \mathrm{a}$ & $50.9 \mathrm{a}$ & 1.74 & 43.5 & $342.0 \mathrm{~b}$ & $127.4 \mathrm{~b}$ & 38.6 \\
\hline $\begin{array}{l}350 \mathrm{mg} \mathrm{L}^{-1} \mathrm{MM}+ \\
0.8 \mathrm{mg} \mathrm{L}^{-1} \mathrm{BA}\end{array}$ & $32.8 \mathrm{~b}$ & $54.4 \mathrm{a}$ & 1.41 & 46.4 & $313.8 \mathrm{~b}$ & $143.8 \mathrm{a}$ & 55.5 \\
\hline $700 \mathrm{mg} \mathrm{L}^{-1} \mathrm{MM}$ & $37.0 \mathrm{~b}$ & $52.7 \mathrm{a}$ & 1.17 & 28.7 & $192.2 \mathrm{~b}$ & $148.3 \mathrm{a}$ & 41.1 \\
\hline $\begin{array}{l}700 \mathrm{mg} \mathrm{L}^{-1} \mathrm{MM}+ \\
0.8 \mathrm{mg} \mathrm{L}^{-1} \mathrm{BA}\end{array}$ & $63.0 \mathrm{a}$ & $69.4 \mathrm{a}$ & 1.78 & 62.5 & $471.0 \mathrm{a}$ & $133.7 \mathrm{~b}$ & 55.5 \\
\hline \multirow[t]{2}{*}{ CV $(\%)$} & 51.5 & 40.5 & 31.0 & 48.2 & 28.2 & 9.3 & 40.4 \\
\hline & \multicolumn{7}{|c|}{ - ------2014/2015------- } \\
\hline $\begin{array}{l}\text { Control } \\
\text { (No thinning) }\end{array}$ & $78.1^{\text {ns }}$ & $21.9^{\mathrm{ns}}$ & $1.8^{\text {ns }}$ & $43.7 \mathrm{a}$ & $417.5 \mathrm{a}$ & $105.4^{\mathrm{ns}}$ & - \\
\hline Hand thinning & 67.4 & 49.7 & 1.4 & $44.4 \mathrm{a}$ & $397.5 \mathrm{a}$ & 111.9 & - \\
\hline $350 \mathrm{mg} \mathrm{L}^{-1} \mathrm{MM}$ & 95.8 & 35.6 & 1.9 & $49.3 \mathrm{a}$ & $444.0 \mathrm{a}$ & 111.8 & - \\
\hline $\begin{array}{l}350 \mathrm{mg} \mathrm{L}^{-1} \mathrm{MM}+ \\
0.8 \mathrm{mg} \mathrm{L}^{-1} \mathrm{BA}\end{array}$ & 52.2 & 31.4 & 1.7 & $32.1 \mathrm{~b}$ & $267.2 \mathrm{~b}$ & 124.9 & - \\
\hline $700 \mathrm{mg} \mathrm{L}^{-1} \mathrm{MM}$ & 51.3 & 32.2 & 1.6 & $17.2 \mathrm{~b}$ & $137.7 \mathrm{~b}$ & 125.1 & - \\
\hline $\begin{array}{l}700 \mathrm{mg} \mathrm{L}^{-1} \mathrm{MM}+ \\
0.8 \mathrm{mg} \mathrm{L}^{-1} \mathrm{BA}\end{array}$ & 81.2 & 32.3 & 1.6 & $30.2 \mathrm{~b}$ & $256.8 \mathrm{~b}$ & 118.3 & - \\
\hline CV $(\%)$ & 30.9 & 31.9 & 20.0 & 38.4 & 21.5 & 11.3 & - \\
\hline
\end{tabular}

MM: metamitron; BA: benzyladenine; VC (\%): variation coefficient. Averages followed by the same letter in the column do not differ by the Scott-Knott's test at $5 \%$ probability. ns: not significant $(\mathrm{P}>0.05)$.

TABLE 4- Fruit distribution by size in 'Fuji' apple trees submitted to different thinning treatments, in the 2013/2014 and 2014/2015 crop seasons. Caçador, SC, 2015.

\begin{tabular}{|c|c|c|c|c|c|c|}
\hline \multirow{3}{*}{ Treatments } & \multicolumn{6}{|c|}{ Distribution of fruits per size $(\%)$} \\
\hline & $<135$ & $150-165$ & $>180$ & $<135$ & $150-165$ & $>180$ \\
\hline & \multicolumn{3}{|c|}{---------2013/2014--------- } & \multicolumn{3}{|c|}{---------2014/2015--------- } \\
\hline Control (No thinning) & $17.1 \mathrm{~b}$ & $47.9^{\mathrm{ns}}$ & $35.0 \mathrm{a}$ & $14.2 \mathrm{~b}$ & $35.5^{\mathrm{ns}}$ & $50.3 \mathrm{a}$ \\
\hline Hand thinning & $19.3 \mathrm{~b}$ & 49.9 & $30.8 \mathrm{a}$ & $12.5 \mathrm{~b}$ & 45.7 & $41.8 \mathrm{a}$ \\
\hline $350 \mathrm{mg} \mathrm{L}^{-1} \mathrm{MM}$ & $24.2 \mathrm{~b}$ & 52.4 & $23.5 \mathrm{~b}$ & $11.8 \mathrm{~b}$ & 38.0 & $50.2 \mathrm{a}$ \\
\hline $350 \mathrm{mg} \mathrm{L}^{-1} \mathrm{MM}+0.8 \mathrm{mg} \mathrm{L}^{-1} \mathrm{BA}$ & $33.9 \mathrm{a}$ & 45.2 & $20.9 \mathrm{~b}$ & $21.5 \mathrm{a}$ & 44.2 & $34.3 \mathrm{~b}$ \\
\hline $700 \mathrm{mg} \mathrm{L}^{-1} \mathrm{MM}$ & $38.3 \mathrm{a}$ & 48.8 & $12.9 \mathrm{~b}$ & $27.2 \mathrm{a}$ & 38.3 & $34.5 \mathrm{~b}$ \\
\hline $700 \mathrm{mg} \mathrm{L}^{-1} \mathrm{MM}+0.8 \mathrm{mg} \mathrm{L}^{-1} \mathrm{BA}$ & $35.0 \mathrm{a}$ & 48.2 & $16.8 \mathrm{~b}$ & $20.7 \mathrm{a}$ & 46.3 & $33.0 \mathrm{~b}$ \\
\hline $\mathrm{CV}(\%)$ & 12.3 & 6.0 & 18.1 & 22.9 & 12.9 & 12.4 \\
\hline
\end{tabular}

MM: metamitron; BA: benzyladenine; VC (\%): variation coefficient. size > 135 (fruit weighing more than $141 \mathrm{~g}$ ); size from 150 to 165 (fruit with weight ranging from 105 to $141 \mathrm{~g}$ ); size $\geq 180$ (fruit with weight equal to or less than $104 \mathrm{~g}$ ). Averages followed by the same letter in the column do not differ by the Scott-Knott's test at 5\% probability. ns: not significant ( $\mathrm{P}>0.05)$. 


\section{CONCLUSIONS}

There is an effect of the time of metamitron application on the chemical thinning of 'Baronesa' apple tree, and when applied at petal fall, it promotes adequate adjustment of the productive capacity of plants.

The metamitron concentration is inversely proportional to the production per plant and directly proportional to the increase of the allocation of fruits in the higher size categories. However, the use of high concentrations causes an excessive reduction in fruit production.

The mixture of metamitron and benzyladenine promotes a reduction in the number of fruits per plant. However, there is no additive effect on fruit drop between mixture with benzyladenine and single application of metamitron.

\section{ACKNOWLEDGMENTS}

To the Scholarship Program of the Support Fund for the Maintenance and Development of Higher Education - FUMDES for granting the scholarship to the first author.

\section{REFERENCES}

BASAK, A. Efficiency of fruitlet thinning in apple 'Gala Must' by use of metamitron and artificial shading. Journal of Fruit and Ornamental Plant Research, Skierniewice, v.19, p.51-62, 2011.

BRUNNER, P. Impact of metamitron as a thinning compound on apple plants. Acta Horticulturae, The Hague, v.1042, p.173-181, 2014.

CAMILO, A.P.; DENARDI, F. Cultivares: descrição e comportamento no sul do Brasil. In: EPAGRI. A cultura da macieira, Florianópolis, 2006, p.113168.

COSTA, G.; BONANY, J.; CARBO, J.; CASALS, M.; STOPAR, M.; LAFER, G.; DORIGONI, A.; VIZZOTTO, G.; BOMBEN, C. Multilocation analysis of ATS and BA thinning efficacy on 'Golden Delicious'. Acta Horticulturae, The Hague, v.636, p.303-310, 2004.

COSTA, G.; DAL CIN, V.; RAMINA, A. Physiological, molecular and practical aspects of fruit abscission.Acta Horticulturae, The Hague, v.727, p.301-310, 2006.
FALLAHI, E.; GREENE, D.W. The impact of blossom and postbloom thinners on fruit set and fruit quality in apples and stone fruits. Acta Horticulturae, The Hague, v.884, p.179-187 2010.

FERREIRA, D.F. SISVAR - programa estatístico Versão 5.3 (Build 75). Lavras: Universidade Federal de Lavras, 2010.

GREENE, D.W. Use of metamitron alone and in combination with 6-benzyladenine for thinning APPLES. Acta Horticulturae, The Hague, v.1042, p.167-172, 2014.

LAFER, G. Effects of chemical thinning with metamitron on fruit set, yield and fruit quality of 'Elstar'. Acta Horticulturae, The Hague, v.884, p.531-536, 2010.

MCARTNEY, S.J.; OBERMILLER, J.D. Use of 1-aminocyclopropane carboxylic acid and metamitron for delayed thinning of apple fruit. HortScience, Alexandria, v.47, n.11, p.1612-1616, 2012.

MCARTNEY, S.J.; OBERMILLER, J.D. Use of shading and the psII inhibitor metamitron to investigate the relationship between carbohydrate balance and chemical thinner activity in apples. Acta Horticulturae, The Hague, v.1042, p.27-31, 2014.

PETRI, J.L. LEITE, G.B.; BASSO, C. Chemical thinning of 'Fuji' apples growing in a mild winter climate. Acta Horticulturae, The Hague, v.727, p.429-436, 2006.

PETRI, J.L.; HAWERROTH, F.J.; LEITE, G.B COUTO, M. Raleio químico em macieiras 'Fuji Suprema' e 'Lisgala'. Revista Brasileira de Fruticultura, Jaboticabal, v.35, n.1, p.170-182, 2013.

REIGHARD, G.L.; OUELLETTE, D.R.; BROCK, K.H. Pre-bloom thinning of peach flower buds with soybean oil in South Carolina. Acta Horticulturae, The Hague, v.727, p 345-351, 2006.

SCOLARO, A.M.T.; ARGENTA, L.C.; AMARANTE, C.V.T.; PETRI, J.L.; HAWERROTH, F.J. Controle da maturação pré-colheita de maçãs 'Royal Gala' pela inibição da ação ou síntese do etileno. Revista Brasileira de Fruticultura, Jaboticabal, v.37, n.1, p.38-47, 2015. 
STERN, R.A. The photosynthesis inhibitor metamitron is an effective fruitlet thinner for 'Gala' apple in the warm climate of Israel. Scientia Horticulturae, Amesterdan, v.178, p.163-167, 2014.
STOVER, E.; DAVIS, K.; WIRTH, F. Economics of fruit thinning: a review focusing on apple and citrus. HortTechnology, Alexandria, v.14, p.282-289, 2004. 